\title{
O conto do cadáver que pertencia não se sabe a quem, de Vladímir Odóievski
}

Lucas Simone

Resumo: Tradução comentada de conto de Vladímir Odóievski.

Palavras-chave: Traducão; Literatura russa; Vladimir Odóievski

\section{Apresentação}

Embora seu nome soe pouco ou nada familiar ao leitor de fora da Rússia, o príncipe Vladímir Fiódorovitch Odóievski (1804-69) produziu, ao longo de sua vida, uma das mais versáteis e curiosas obras da literatura russa do século XIX. Sua pena gerou de livros infantis a ensaios filosóficos, de teoria musical a resenhas gastronômicas. Tido como uma espécie de homem renascentista, devido a seu conhecimento enciclopédico e a seu interesse pelos mais diversos assuntos, foi membro ativo de inúmeros grupos literários e filosóficos, dentre eles a Sociedade dos Amantes da Sabedoria (os chamados Liubomúdry), além de editar o periódico Mnemozina. Grande propagador da filosofia idealista e do romantismo alemão, trouxe ao público russo autores como Novalis e Schelling, do qual foi manifesto admirador - essa filiação à literatura germânica, aliás, deixou marcas inequívocas em seus escritos, rendendo-lhe o epíteto de "Hoffmann Russo".

No conto que aqui apresentamos, porém, estão presentes ressonâncias menos alemãs do que tipicamente russas; mais precisamente, é nítido o diálogo com um dos grandes nomes da literatura russa, Nikolai Gógol, de cujas Noites numa granja próximo de Dikanka Odóievski extrai sua epígrafe. "O conto do cadáver que pertencia não se sabe a quem" remeterá o leitor habituado às singulares linhas gogolianas a um ambiente familiar: o da Rússia profunda, rural, com seus buro- 
cratas de província e seus funcionários corruptos, colocados frente a um elemento sobrenatural, grotesco e inusitado, igualmente caro a Gógol e Odóievski, os dois maiores mestres da narrativa fantástica na Rússia.

O texto a seguir foi publicado em 1833, dentro do volume Contos variegados com um gracejo, coletânea esta que não recebeu acolhida calorosa do leitor russo. A própria mãe de Odóievski teria afirmado, em carta ao filho, que as narrativas encerradas no livro eram por demais díspares, e que a incompreensão do público era previsível. Não à toa, o ciclo de histórias só voltaria ao papel em sua ordem original numa edição em língua russa publicada na Inglaterra em 1988. "O conto do cadáver que pertencia não se sabe a quem”, porém, apareceria em várias edições das obras reunidas do autor, bem como em coletâneas publicadas em língua estrangeira.

\section{O conto do cadáver que pertencia não se sabe a quem}

É fato que o escrivão provincial, saindo de quatro da taverna, vin que a lua, sem mais nem menos, dançava no céu, e jurou para todo o povoado que era verdade; mas os aldeões balançaram a cabeşa e até zombaram dele.

Gógol, nas Noites numa granja...

Aos povoados comerciais do distrito de Rejensk, foi emitida, por parte do tribunal do ziémstvo, a seguinte declaração:

"Em nome do tribunal do ziémstvo de Rejensk, declara-se que, em sua jurisdição, nos pastos do vilarejo de Morkóvkino-Natáchino, aos 21 do corrente mês de novembro, foi encontrado morto um corpo do sexo masculino, de dono desconhecido, vestido com um velho capote de feltro cinza, com uma cinta de linha, um colete de feltro de cor vermelha e em parte verde, com uma camisa de chita vermelha; na cabeça, havia um quepe feito com velhos trapos de chita, com viseira de couro; o falecido tem aproximadamente 43 anos de idade, 2 archines e 10 verchoks de altura, ${ }^{1}$ cabelos castanho-claros, rosto branco, liso, olhos cinzentos, barba feita, queixo com pelos grisalhos, nariz grande e um pouco para o lado, compleição fraca. Assim, por meio desta declara-se: se houver ex-parentes do referido corpo ou o proprietário do referido corpo, roga-se que se manifestem

1 Antigas medidas russas: o archin equivalia a $71 \mathrm{~cm}$, enquanto o verchok equivalia a 4,4 cm. Era costume dizer a altura em verchoks acima de dois archines. O morto tinha, portanto, 1,86 m de altura. (N. do T.) 
no povoado de Morkóvkino-Natáchino, onde está sendo conduzido inquérito sobre o corpo, pertencente não se sabe a quem; e se não os houver, roga-se que se manifestem a esse respeito nesse mesmo povoado de Morkóvkino".

Três semanas se passaram na espera dos proprietários do cadáver; ninguém apareceu, e finalmente o assessor e o médico do distrito foram visitar o proprietário de terras em Morkóvkino; numa isbá sem dono, separaram um quarto para o amanuense Sevastiánytch, que também fora enviado para o inquérito. Nessa mesma isbá, no fundo da despensa, encontrava-se o cadáver, que o tribunal pretendia dissecar e enterrar no dia seguinte, pelo procedimento comum. O afável proprietário, para consolar Sevastiánytch em sua solidão, enviou-lhe do pátio senhorial um ganso com molho e um jarro de licor caseiro para o estômago.

Já anoitecera. Sevastiánytch, homem ordeiro que era, em vez de seguir o costume de seus confrades e trepar no poláti ${ }^{2}$ que ficava junto ao forno ainda há pouco aceso, julgou por bem dedicar-se à preparação dos papéis para a sessão do dia seguinte, ainda mais pela consideração de que, embora do ganso tivessem restado apenas os ossos, só um quarto do jarro tinha sido esvaziado; antes de tudo ele ajeitou o castiçal na cabeceira de ferro, que o estaroste do povoado de Morkóvkino mantivera ali propositalmente, para casos como aquele, e depois tirou de sua bolsa de couro um caderno velho e ensebado. Sevastiánytch não podia olhar para ele sem se enternecer; eram cópias de diversos decretos relacionados a assuntos do ziémstvo, que lhe foram deixados como herança pelo pai, escrivão subscritor de saudosa memória - afastado do cargo na cidade de Rejensk por denúncias de concussão e comportamento indecente, com a recomendação, aliás, de que dali em diante não fosse nomeado em lugar algum e de que não fosse aceita petição nenhuma por parte dele - pelo que ele gozava do respeito de todo o distrito. Sevastiánytch involuntariamente recordava que esse caderninho era o único código a nortear o tribunal do ziémstvo de Rejensk em suas ações; que somente Sevastiánytch podia ser o intérprete dos misteriosos símbolos daquele Livro Sibilino; que por meio de seu poder mágico ele mantinha submissos tanto o comissário de polícia, como os assessores, e forçava todos os habitantes da repartição a virem até ele em busca de conselhos e instruções; e era por isso que ele o guardava como a menina dos olhos, não o mostrava a ninguém e tirava-o do fundo da arca só em caso de extrema necessidade; com um risinho, ele parava nas páginas em que, em parte pelas mãos de seu finado pai e em parte por suas próprias mãos, estavam ora manchadas, ora novamente escritas diversas partículas insignificantes, tais como:

2 Tradicional leito que se afixava em cima dos grandes fornos russos. (N. do T.) 
"não", "mas", "e" etc., e da maneira mais natural vinha à mente de Sevastiánytch: como eram estúpidas as pessoas, e como eram inteligentes ele e seu pai.

Enquanto isso, ele esvaziou o segundo quarto do jarro e começou a trabalhar; mas enquanto sua habituada mão traçava com rapidez ganchinhos no papel, seu amor-próprio, desperto pela visão do caderno, trabalhava: ele recordava quantas vezes ele transportara cadáveres para lá da divisa de um distrito vizinho, livrando assim seu comissário de preocupações supérfluas: e no mais: se fosse para elaborar uma sentença, tomar informações, fundamentas as leis, entrar em contato com os peticionários, informar a chefia acerca da impossibilidade de cumprir suas disposições - em toda parte e para tudo havia Sevastiánytch; com um sorriso, ele recordava um expediente inventado por ele: toda busca geral direcionar para o outro lado; ele recordava que, recentemente, por meio desse inocente método, salvara um de seus favorecidos: esse favorecido fizera certa coisinha graças à qual poderia facilmente empreender uma viagem não de todo agradável; foi feito o interrogatório, deram o mandado de busca - mas nessa ocasião Sevastiánytch sugeriu de inquirir em primeiro lugar um rapaz alfabetizado, da parte de seu favorecido; de acordo com as palavras do rapaz alfabetizado, foi escrito um papel, que o rapaz alfabetizado, persignando-se, assinou, e o próprio Sevastiánytch foi ter com um cidadão, depois com outro, e com um terceiro, indagando: "Você também, você também?" - e começou a revisá-los com tanta rapidez, que, enquanto os cidadãos ainda estavam boquiabertos e apresentavam seus cumprimentos, preparando-se para responder - ele conseguiu interrogar a todos, até o último, e novamente o rapaz alfabetizado, por conta do desconhecimento das letras de seus camaradas, assinou, persignando-se, seu testemunho unânime. Com semelhante satisfação, Sevastiánytch recordava quando um desconto significativo foi imposto ao comissário, e ele conseguiu implicar no caso umas quinze pessoas, dividir o desconto entre a turma toda, e depois anistiá-los todos. - Resumindo, Sevastiánytch via que, em todos os casos famosos do tribunal do ziémstvo de Rejensk, ele era o único culpado, o único maquinador e o único executor; que, sem ele, estaria arruinado o assessor, estaria arruinado o comissário, estariam arruinados tanto o juiz de distrito, como o chefe de distrito; que somente por ele mantinha-se a antiga glória do distrito de Rejensk - e involuntariamente passou pela mente de Sevastiánytch a doce sensação do próprio mérito. É verdade que, de longe - como que das nuvens -cintilavam em seus olhos os olhos enervados do governador, o rosto inquiridor do secretário da câmara criminal; mas ele olhou para as janelas encobertas pela nevasca; pensou nas trezentas verstas que o separavam de tão horrível visão; para aumentar o ânimo, bebeu o terceiro quarto do jarro, e seus pensamentos ficaram muito mais alegres: ele imaginou sua alegre casinha em Rejensk, ganha com seu 
intelecto; os garrafões de licor de fruta na janela, entre dois vasos de balsamina; o armário de louça e, em meio à louça, no meio, num lugar de honra, o pimenteiro de cristal com pires de porcelana; lá vem sua Lukéria Petrovna, corpulenta e de rosto branco; em suas mãos está um redondo e adocicado pão de grãos; uma bezerra que foi cevada para as festividades natalinas olha para Sevastiánytch; uma grande chaleira e um samovar saúdam-no e movem-se em sua direção; eis aí seu cálido leito junto ao forno, e, junto ao leito, um colchão de penas com uma manta bordada, e, debaixo da manta, um retalho dobrado de chita, e, na chita, um pano de linho branco, e, no pano de linho, uma carteira de couro, e, na carteira de couro, umas notas cinzentas; - nesse ponto, a imaginação de Sevastiánytch transportou-o aos anos de sua juventude, ele se lembrou de sua pobre vidinha na casa do pai; da frequência com que passava fome graças à avareza da mãe; de como ele foi enviado ao sacristão para aprender a ler - de coração, ele gargalhou ao relembrar uma vez em que, junto com seus camaradas, ele invadiu o jardim de seu professor para pegar maçãs e assustou o sacristão, que o tomou por um ladrão de verdade; lembrou-se de como foi açoitado por isso e de como, para se vingar, deu comida gorda para seu professor bem na Sexta-Feira Santa; depois ele se lembrou: de como ele finalmente deixou para trás todos os seus coetâneos e chegou ao ponto de ler os Apóstolos na paróquia, começando com o baixo mais profundo e terminando com a vozinha mais fina, para espanto de toda a cidade; de como o comissário, percebendo que a criança daria proveito, alistou-o no tribunal do ziémstvo; de como ele começou a ganhar consciência; contraiu matrimônio com sua queridíssima Lukéria Petrovna; obteve a patente de registrador de província, ${ }^{3}$ na qual se encontra até o presente dia, acumulando bens; seu coração derreteu-se de comoção, e de alegria ele esvaziou o último quarto da encantadora bebida. Nesse ponto, veio à mente de Sevastiánytch que ele não era um finório só na repartição, mas por toda parte: o gosto com que o ouviam quando, no momento mais animado da festinha, ele começava a contar de Bova Korolévitch, ${ }^{4}$ das aventuras de Vanka Kain, ${ }^{5}$ da viagem do mercador Korobéinikov a Jerusalém ${ }^{6}$ - era como um gúsli incessante, isso sim! - e Sevastiánytch começou a sonhar: como seria bom se ele tivesse a força de Bova Korolévitch e pudesse pegar alguém pela mão - e

3 Não havia tal patente na escala do funcionalismo público russo. (N. do T.)

4 Herói de diversas canções populares russas. (N. do T.)

5 Famoso ladrão moscovita do século XVIII, tornou-se personagem recorrente do folclore. (N. do T.)

6 Relato pseudo-histórico do século XVII acerca da viagem que um mercador russo teria feito a Jerusalém no século XVI. (N. do T.)

7 Tradicional instrumento russo de cordas, semelhante à harpa. (N. do T.) 
essa mão seria arrancada; pegar alguém pela cabeça - e essa cabeça seria arrancada; depois teve vontade de ver como era essa tal ilha do Chipre que, como descreve Korobéinikov, é farta em azeite e sabão grego, onde as pessoas andam de burro e de camelo, e ele começou a rir dos habitantes de lá, que não tinham pensado em amarrá-los a um trenó; aí em sua cabeça começaram uns pensamentos: ele achou que, ou nos livros tinham escrito mentiras, ou no geral os gregos deviam ser um povo muito estúpido, porque ele mesmo perguntara - a uns gregos que vieram à feira de Rejensk com sabão e pães de mel e que supostamente deveriam saber o que se faz na terra deles - por que eles tomaram a cidade de Troia - como escreve precisamente Korobéinikov - mas cederam Constantinopla aos turcos! E ele não conseguiu arrancar daquele povo nada que fizesse sentido: os gregos não conseguiram lhe dizer que Troia era aquela, dizendo que provavelmente essa cidade tinha sido construída e tomada na ausência deles; enquanto ele se ocupava com tão importante questão, diante de seus olhos passavam: bandoleiros árabes; o mar Morto; a procissão do sepultamento do gato; ${ }^{8}$ as câmaras do Faraó, todas banhadas a ouro por dentro; o pássaro avestruz, da altura de um homem, com uma cabeça de pato, com uma pedra no casco...

Suas reflexões foram interrompidas pelas seguintes palavras, que alguém pronunciou ao seu lado:

- Meu caro Ivan Sevastiánytch! Venho lhe pedir encarecidamente.

Essas palavras lembraram Sevastiánytch de seu papel de funcionário público, e ele, seguindo seu costume, pôs-se a escrever muito mais depressa, abaixou a cabeça o máximo que pôde e, sem tirar os olhos do papel, respondeu com voz arrastada:

- O que deseja?

- Os senhores do tribunal convocaram os proprietários do cadáver recolhido em Morkóvkino.

- Pois si-im.

- Bem, veja o senhor, esse corpo é meu.

- Pois si-im.

- Então o senhor poderia fazer o obséquio de me devolver o corpo o quanto antes?

8 Referência ao lubok. Como os ratos enterraram o gato, uma das mais famosas obras da arte popular russa. (N. do T.) 
- Pois si-im.

- E o senhor pode contar com minha gratidão...

- Pois si-im. E o que era o falecido, seu servo, por acaso?...

- Não, Ivan Sevastiánytch, que servo. O corpo é meu, é meu próprio corpo...

- Pois si-im.

- O senhor pode imaginar minha situação sem corpo... faça a fineza, ajude-me o mais depressa possível.

- Tudo é possível, meu senhor, mas é um pouquinho difícil resolver esse caso rapidamente - afinal, isso não é uma panqueca, que dá para enrolar com o dedo; é necessário coletar informações... Se molhar um pouquinho a mão...

- Mas não duvide disso - só me entregue meu corpo, e eu não pouparei nem cinquenta rublos...

Ao ouvir essas palavras, Sevastiánytch ergueu a cabeça, mas, sem ver ninguém, disse:

- Mas entre aqui, por que ficar no frio?

- Mas eu estou aqui, Ivan Sevastiánytch, estou parado do seu lado.

Sevastiánytch ajeitou a luminária, esfregou os olhos, sem ver nada, balbuciou:

- Arre, vá para o inferno! - Mas eu fiquei cego ou o quê? Não consigo vê-lo, senhor.

- Não tem nada de mais! Como é que o senhor iria me ver? Eu estou sem corpo!

- Confesso que não entendo bem a fala do senhor, deixe-me pelo menos dar uma olhada.

- Pois não, posso me revelar ao senhor por um momento... só que isso é muito difícil para mim...

E com essas palavras num canto escuro começou a surgir um rosto sem forma; ora aparecia, ora de novo sumia, como um jovem que vai ao baile pela primeira vez - ele quer se aproximar das damas e tem medo, coloca o rosto para fora da multidão e de novo se esconde...

- Perdão, senhor - disse a voz, enquanto isso -, faça o obséquio, perdão, o senhor não pode imaginar como é difícil mostrar-se sem corpo!... faça o obséquio, entregue-me o corpo o quanto antes - estou dizendo que não vou poupar os cinquenta rublos. 
- Fico feliz em servi-lo, meu senhor, mas confesso que não entendo bem a sua fala... o senhor tem um requerimento?...

- Com o seu perdão, que requerimento? Como eu poderia tê-lo escrito sem corpo? Pois faça o obséquio, o senhor tenha a bondade de fazer.

- É fácil dizer, meu senhor, tenha a bondade de fazer, estou lhe dizendo que não entendo patavina...

- Pois só escreva, vou ditar para o senhor.

Sevastiánytch puxou uma folha de papel timbrado.

- Faça o obséquio de dizer: o senhor tem pelo menos patente, nome e patronímico?

- Como não?... Eu me chamo Tsveerlei, John Louis.

- Sua patente, meu senhor?

- Estrangeiro.

E Sevastiánytch escreveu na folha timbrada com letras graúdas:

"Ao tribunal do ziémstvo de Rejensk, da parte do jovem nobre estrangeiro Saviéli Jáluiev, uma explicação".

- E depois?

- Faça o favor de só escrever, eu já vou lhe ditar; escreva: possuo...

- Seria um bem imóvel? - perguntou Sevastiánytch.

- Não, senhor: possuo infelizmente um fraco...

- Por bebidas fortes, é isso? Ah, isso não é nada louvável...

- Não, senhor: possuo infelizmente um fraco por sair do meu corpo...

- Mas que diabo! - exclamou Sevastiánytch, jogando a pena. - Mas o senhor está me ludibriando!

- Eu lhe garanto que estou falando a mais pura verdade, escreva, mas saiba: cinco rublos para o senhor por um só requerimento, e mais cinquenta quando o senhor resolver o caso...

E Sevastiánytch novamente tomou a pena.

"Aos 20 de outubro viajava eu de quibitca, por necessidade minha, pela estrada de Rejensk, na parte da carroça, e como fazia frio na rua, e as vias do distrito de Rejensk são particularmente ruins..."

- Não, mas quanto a isso o senhor me perdoe - objetou Sevastiánytch -, não posso escrever isso de jeito nenhum, isso é pessoal, e incluir coisas pessoais em requerimentos é proibido por decreto... 
- Por mim, pode ser; bom, então simplesmente: na rua estava tão frio, que eu fiquei com medo de congelar a alma, e no mais me deu tanta vontade de chegar logo à pousada... que eu não aguentei... e, de acordo com o meu hábito e costume, saltei para fora do meu corpo...

- Com seu perdão! - exclamou Sevastiánytch.

- Está tudo certo, está tudo certo, continue; o que fazer se eu tenho esse costume?... pois não há nada de ilegal nisso, há?

- Pois nã-ão - respondeu Sevastiánytch -, e depois?

- Queira escrever: saltei para fora do meu corpo, acomodei-o direitinho na parte de dentro da quibitca... para que ele não caísse, amarrei suas mãos com as rédeas e parti para a estação, na esperança de que o próprio cavalo correria para sua estrebaria conhecida...

-É preciso reconhecer-observou Sevastiánytch - que nesse caso o senhor agiu de modo bastante imprudente.

- Ao chegar à estação, trepei no forno para aquecer a alma, e quando, pelos meus cálculos, o cavalo deveria ter voltado à hospedaria... eu saí para encontrá-lo, e no entanto, ao longo de toda aquela noite, nem o cavalo nem o corpo retornaram. No outro dia, de manhã, fui depressa ao local em que havia deixado a quibitca... mas ela também não estava mais lá... suponho que meu corpo inerte tenha caído da quibitca por causa dos buracos na estrada e tenha sido recolhido por um comissário que passava, e que o cavalo tenha ido na rabeira de um comboio... Depois de três semanas de buscas infrutíferas, eu, tomando agora conhecimento da declaração do tribunal do ziémstvo de Rejensk, por meio da qual foram conclamados os proprietários de um corpo que havia sido encontrado, venho rogar encarecidamente que meu corpo me seja entregue, como seu proprietário legal... a que adiciono o pedido encarecido ao supracitado tribunal de que me conceda o beneplácito de ordenar que meu corpo seja previamente mergulhado em água fria, para que ele se recupere; e se, por conta da queda ocorrida, houver no reiteradamente referido corpo algum defeito ou se ele tiver sido danificado em algum local pelo frio, então que seja ordenado ao médico do distrito que o conserte às minhas custas e que tudo isso seja feito conforme determinam as leis, a que me subscrevo.

- Bem, queira então assinar - disse Sevastiánytch depois de concluir o papel.

- Assinar! É fácil dizer! Estou lhe dizendo que agora não estou com minhas mãos aqui comigo - elas ficaram com o corpo; assine o senhor por mim, dada a ausência de mãos... 
- Não! Perdão - objetou Sevastiánytch -, não tem modelo para isso, e é proibido aceitar por decreto os requerimentos que são escritos fora do modelo; se o senhor quiser: por ausência de alfabetização...

- Como o senhor houver por bem! Por mim tanto faz.

E Sevastiánytch assinou: "A essa explicação, por ausência de alfabetização, a pedido do próprio requerente, o registrador de província Ivan Sevastiánytch, filho dos Blagosiérdov, colocou sua assinatura de próprio punho".

- Fico-lhe profundamente agradecido, honorabilíssimo Ivan Sevastiánytch! Bem, agora cuide o senhor para que esse caso seja resolvido logo; não pode imaginar como é incômodo ficar sem corpo!... e eu agora vou correndo ver minha esposa, mas tenha certeza de que não vou privá-lo de nada.

- Espere, espere, vossa honra! - exclamou Sevastiánytch. - Há uma contradição no requerimento. Como é que, sem as mãos, o senhor se acomodou ou acomodou seu corpo na quibitca? Arre, ao diabo com isso, não entendo nada.

Mas não houve resposta. Sevastiánytch leu mais uma vez o requerimento, começou a pensar nele, pensou, pensou...

Quando ele acordou, a lâmpada de cabeceira estava apagada, e a luz matinal despontava pela janela coberta com uma bolsa. Com desgosto ele olhou para o jarro vazio que estava diante dele; esse desgosto arrancou-lhe da cabeça o acontecimento noturno; ele recolheu seus papéis sem olhar e partiu para o pátio senhorial, na esperança de tomar uma para rebater a ressaca.

$\mathrm{O}$ assessor, depois de tomar uma tacinha de vodca, começou a examinar os papéis de Sevastiánytch e deu com o requerimento do jovem nobre estrangeiro.

-É, irmão Sevastiánytch - exclamou ele, depois de ler -, ontem antes de dormir você puxou bem; mas que besteirada escreveu! Ouça isso, Andrei Ignátievitch - ele acrescentou, dirigindo-se ao médico do distrito -, veja que tipo de peticionário o Sevastiánytch nos trouxe. - E ele leu para o médico do distrito o curioso requerimento, palavra por palavra, quase morrendo de rir.

- Vamos, senhores - disse ele, finalmente -, vamos dissecar esse corpo falastrão, e se ele não der sinal de vida, aí nós o enterramos por bem ou por mal; está na hora de ir à cidade.

Essas palavras fizeram Sevastiánytch recordar-se do acontecimento noturno, e, por mais estranho que aquilo lhe parecesse, ele se lembrou dos cinquenta rublos prometidos pelo peticionário se ele obtivesse o corpo e, com seriedade, começou a exigir do assessor e do médico que não dissecassem o corpo, porque isso poderia 
estragá-lo, de tal modo que ele já não prestaria para nada, e que se desse entrada no requerimento de acordo com o procedimento comum.

É evidente que responderam a essa exigência de Sevastiánytch com o conselho de que ficasse sóbrio; dissecaram o corpo, não encontraram nada nele e o enterraram.

Depois desse acontecimento, o requerimento do defunto começou a passar de mão em mão; por toda parte ele era copiado, complementado, enfeitado, lido, e por muito tempo as velhinhas de Rejensk se benzeram ao ouvi-lo, horrorizadas.

A lenda não manteve o desfecho desse acontecimento incomum: em um distrito vizinho, contavam que, no preciso momento em que o médico tocou o corpo com seu bisturi, o proprietário saltou no corpo, o corpo se levantou, saiu correndo, e que Sevastiánytch ficou um bom tempo correndo atrás dele pelo vilarejo, gritando com todas as forças: "Peguem, peguem o falecido!".

Já num outro distrito, asseguram que, até hoje, todo dia o proprietário vai até a casa de Sevastiánytch, de manhã e de noite, dizendo: "Meu caro Ivan Sevastiánytch, e o meu corpo? Quando é que o senhor vai me entregar meu corpo?”-e que Sevastiánytch, sem perder o ânimo, responde: "É que ainda estão recolhendo as informações". Nisso já se passaram vinte anos.

\title{
Сказка о мёртвом теле, неизвестно кому принаАлежащем
}

\begin{abstract}
Правда, волостной писарь, вьгход на четвереньках из шинка, видел, что месяч ни с сего ни с того танщевал на небе, и уверял с божбон в том всё село; но миряне качали головами и даже подымали его на смех.
\end{abstract}

Гоголь, в "Вечерах на хуторе"

По торговым сёлам Реженского уезАа было сделано от земского суда следующее объявление:

“От Реженского земского суда объявцяется, что в ведомстве его, на выгонной земле Аеревни Морковкиной-Наташиной то ж, 21-го минувшего ноября найдено неизвестно чьё мёртвое мужеска пола тело, одетое в серый суконный ветхий шинель; в нитяном кушаке, жилете суконном красного и отчасти зелёного цвета, в рубашке красной пестрядинной; на голове картуз из старых пестрядинных тряпиц с кожаным козырьком; от роду покойному 


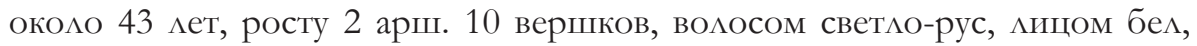
глаАколиц, глаза серые, бороду бреет, подбородок с проседью, нос велик и несколько на сторону, телосложения слабого. По чему сим объяв яется: не окажется $\Lambda и$ оному телу бывших родственников или владельца оного тела; таковые благоволили бы уведомить от себя в село Морковкино-Наташино тож, где и следствие об оном, неизвестно кому принаАлежащем, теле производится; а если таковых не найдётся, то и о том благоволили б уведомить в оное же село Морковкино”.

Три недели прошло в ожидании вцадельцев мёртвого тела; никто не яв яяся, и наконец заседатель с уезАным лекарем отправились к помещику села Морковкина в гости; в выморочной избе отвели квартиру приказному Севастьянычу, также прикомандированному на следствие. В той же избе, в заклети, находилось мёртвое тело, которое назавтра суд собирался вскрыть и похоронить обыкновенным порядком. Аасковый помещик, Аля утешения Севастьяныча в его уединении, прислац ему с барского Авора гуся с подливой Аа штоф Аомашней желудочной настойки.

Уже смерклось. Севастьяныч, как человек аккуратный, вместо того чтоб, по обыкновению своих собратий, взобраться на полати возле только что истопленной печи, рассудиц за благо заняться приготовлением бумаг к завтрашнему заседанию, по тому более уважению, что хотя от гуся осталися одни кости, но только четверть штофа была опорожнена; он предварительно поправиц светильню в железном ночнике, нарочито Аля подобных случаев хранимом старостою села Морковкина, - и потом из кожаного мешка вытащил старую замасленную тетраАку. Севастьяныч не мог на неё смотреть без умиления: то были выписки из разАичных указов, касающихся до земских Аел, Аоставшиеся ему по наследству от батюшки, блаженной памяти подьячего с приписью, - в городе Реженске за ябеды, Аихоимство и непристойное поведение отстав енного от Аолжности, с таковым, впрочем, пояснением, чтобы его впредь никуда не определять и просьб от него не принимать, - за что он и пользовался уважением всего уезда. Севастьяныч невольно вспоминац, что эта тетраАка была еАинственный кодекс, которым руководствовался Реженский земский суд в своих Аействиях; что один Севастьяныч мог быть истолкователем таинственных символов этой Сивиц^иной книги; что посредством её магической силы он Аержац в повиновении и исправника и заседателей и застав $я \Lambda$ всех жителей око отка прибегать к себе за советами и наставцениями; почему он и берёг её как зеницу ока, никому не показывац и вынимац из-под спуда только в случае крайней надобности; с усмешкою он останавАивацся на тех страницах, где 
частию рукою его покойного батюшки и частию его собственною были то замараны, то вновь написаны разные незначащие частицы, как-то: не, а, и и проч., и естественным образом Севастьянычу приходило на ум: как глупы Аюди и как умны он и его батюшка.

Межлу тем он опорожнил вторую четверть штофа и принялся за работу; но пока привычная рука его быстро выгибала крючки на бумаге, его самолюбие, возбужлённое вилом тетраАки, работало: он вспоминал, сколько раз он перевозил мёртвые тела за границу соседнего уезАа и тем избав $А$ своего исправника от изАишних хлопот: Аа и вообще: составить $\Lambda и$

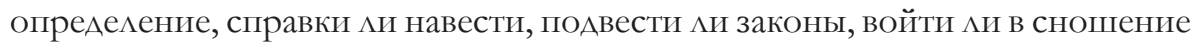

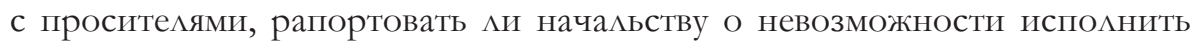
его предписания, - везде и на всё Севастьяныч; с улыбкою вспоминац он

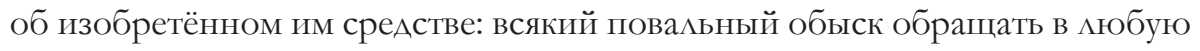
сторону; он вспоминац, как ещё недавно таким невинным способом он спас одного своего благоприятеля: этот благоприятель сделац какое-то Аельце, за которое мог бы мегко совершить некоторое не совсем приятное путешествие; учинён допрос, наряжён повальный обыск, - но при сём случае Севастьяныч надоуми спросить прежде всех одного грамотного молодца с руки его благоприятелю; по словам грамотного молодца написали бумагу, которую грамотный молодец, перекрестяся, подписац, а сам Севастьяныч приступил к одному обывателю, к Аругому, к третьему с вопросом: “И ты тоже, и ты тоже?" - да так скоро начал перебирать их, что, пока обыватели ещё чесали за ухом и кланялись, приготов яясь к ответу, - он успе и их переспросить всех до последнего, и грамотный молодец снова, за неумением грамоты своих товарищей, подписал, перекрестяся, их единогласное показание. C не меньшим удовольствием вспоминац Севастьяныч, как при

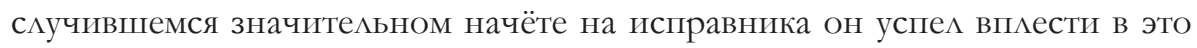
дело человек до пятнадцати, начёт разцожить на всю братию, а потом всех и подвести под милостивый манифест. - Словом, Севастьяныч видец, что во всех знаменитых делах Реженского земского суда он был единственным виновником, единственным выдумщиком и еАинственным исполнителем; что без него бы погиб заседатель, погиб исправник, погиб и уезАный судья, и уезАный предводитель; что им одним держится Аревняя слава Реженского уезАа, - и невольно по Ауше Севастьяныча пробежало слаАкое ощущение собственного достоинства. Правда, издали - как будто из облаков - мелькали

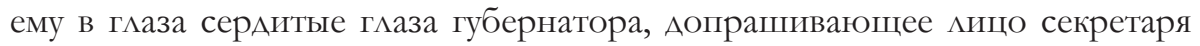
уголовной палаты; но он посмотрел на занесённые метелью окошки; подумац о трёх стах вёрстах, отдецяющих его от сего ужасного призрака; Аля 
увеличения бодрости выпиц третью четверть штофа - и мысли его слелались гораздо веселее: ему представился его весёлый реженский домик, нажитый своим умком; бутыли с наливкою на окошке межАу двумя бальзаминными горошками; шкап с посудою и между нею в средине на почётном месте хрустальная на фарфоровом блюдце перешница; вот илёт его полная белолицая Аукерья Петровна; в руках у ней слобный крупичатый каравай; вот тёлка, откормленная к святкам, смотрит на Севастьяныча; большой чайник с самоваром ему кланяется и подвигается к нему; вот тёплая лежанка,

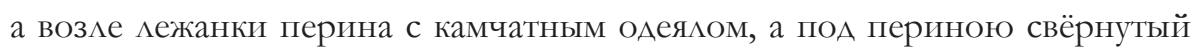
москут пестрядки, а в пестрядке белая холстинка, а в холстинке кожаный книжник, а в книжнике серенькие бумажки; - тут воображение перенесло

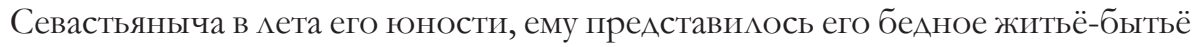
в батюшкином доме; как часто он голодал от матушкиной скупости; как его отАали к Аьячку учиться грамоте, - он от Ауши хохотац, вспоминая, как однажды с товарищами забрался к своему учителю в саА за яблоками и напугал дьячка, который принял его за настоящего вора; как за то был высечен и в отмщение оскороми своего учите яя в самую страстную пятницу; потом представ ялось ему: как наконец он обогнац всех своих сверстников и Аостиг Ао того, что читал апостол в приходской церкви, начиная самым густым басом и кончая самым тоненьким голоском, на удивление всему городу; как исправник, заметив, что в ребёнке будет прок, приписал его к земскому суду; как он начал входить в ум; оженился с своею Аражайшею Аукерьей Петровной; получил чин губернского регистратора, в коем и Аоднесь пребывает да добра наживает; сердце его растаяло от умиления, и он на радости опорожнил и последнюю четверть обворожительного напитка. Тут пришло Севастьянычу в голову, что он не только что в приказе, но хват на все руки: как заслушиваются его, когда он под вечерок в веселый час примется рассказывать о Бове Королевиче, о похожлениях Ваньки Каина, о путешествии купца Коробейникова в Иерусалим, - неумолкаемые гусли, Аа и только! - и Севастьяныч начац мечтать: куда бы хорошо было, если бы у него была сила Бовы Королевича и он бы смог кого за руку - у того рука прочь, кого за голову - у того голова прочь; потом захоте лось ему посмотреть, что за Кипрский таков остров есть, который, как описывает Коробейников,

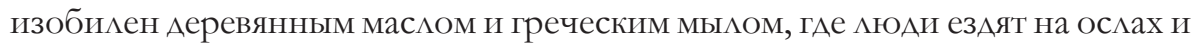
на верблюдах, и он стац смеяться наА тамошними обывателями, которые не могут догадаться запрячь их в сани; тут начались в голове его рассуждения: он нашё , что или в книгах неправду пишут, или вообще греки Аолжны быть народ очень глупый, потому что он сам расспрашивац у греков, приезжавших 
на реженскую ярмарку с мылом и пряниками и которым, кажется, Аолжно было знать, что в их земле делается, - зачем они взяли город Трою, - как именно пишет Коробейников, - а ЦарьграА уступили туркам! и никакого толка от этого народа не мог добиться: что за Троя такая, греки не могли ему рассказать, говоря, что, вероятно, выстроили и взяли этот гороА в их отсутствие; - пока он занимался этим важным вопросом, преА глазами его проходили: и арабские разбойники; и Гнилое море; и процессия погребения кота; и палаты царя Фараона, внутри все вызолоченные; и птица Строфокамиц, вышиною с человека, с утиною головою, с камнем в копыте...

Его размышления были прерваны следующими словами, которые кто-то проговориц подие него:

- Батюшка, Иван Севастьяныч! я к вам с покорнейшею просьбою.

Эти слова напомнили Севастьянычу его ролю приказного, и он, по обыкновению, принялся писать гораздо скорее, наклонил голову как можно ниже и, не сворачивая глаз с бумаги, отвечац протяжным голосом:

- Что вам угодно?

- Вы от суда вызываете владельцев поднятого в Морковкине мёртвого тела.

- Та-ак-с.

- Так изволите видеть - это тело моё.

- Та-ак-с.

- Так нельзя ми мне слелать милость, поскорее его вылать?

- Та-ак-с.

- А уж на благодарность мою надейтесь...

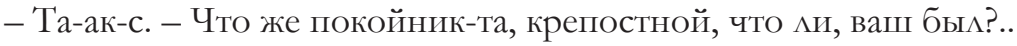

- Нет, Иван Севастьяныч, какой крепостной, это тело моё, собственное моё...

- Та-ак-с.

- Вы можете себе вообразить, каково мне без тела... слелайте одолжение, помогите поскорее.

- Всё можно-с, да трудновато немного скоро-то это дело слелать, ведь оно не блин, кругом пальца не обвернёшь; справки надобно навести... Кабы подмазать немного... 
- Аа уж в этом не сомневайтесь, - выАайте Аишь только моё тело, так я и пятидесяти рублей не пожалею...

При сих словах Севастьяныч поднял голову, но, не виАя никого, сказал:

- Аа войдите сюАа, что на морозе стоять.

- Аа я зАесь, Иван Севастьяныч, возле вас стою.

Севастьяныч поправиц мампадку, протёр глаза, но, не видя ничего, пробормотал:

- Тьфу, к чёрту! - Аа что я, ослеп, что ми? - я вас не вижу, сударь.

- Ничего нет мудрёного! как же вам меня видеть? я - без тела!

- Я, право, в толк не возьму вашей речи, Аайте хоть взглянуть на себя.

- Извольте, я могу вам показаться на минуту... только мне это очень труАно...

И при этих словах в тёмном углу стало показываться какое-то мицо без образа; то явится, то опять пропаАёт, словно молодой человек, в первый раз приехавший на бал, - хочется ему подойти к дамам и боится, выставит Аицо из толпы и опять спрячется...

- Извините-с, - межАу тем говориц голос, - саелайте милость, извините, вы не можете себе вообразить, как трудно без тела показываться!.. сАелайте милость, отАайте мне его поскорее, - говорят вам, что пятидесяти руб̆ей не пожалею.

- РаА вам служить, сударь, но, право, в толк не возьму вашей речи... есть у вас просьба?..

- Помилуйте, какая просьба? как мне было без тела её написать? уж сАелайте милость, вы сами потрудитесь.

- егко сказать, сударь, потрудиться, говорят вам, что я тут ни черта не понимаю...

- Уж пишите только, - я вам буду сказывать.

Севастьяныч вынул Аист гербовой бумаги.

- Скажите, слелайте милость: есть ми у вас по крайней мере чин, имя и отчество?

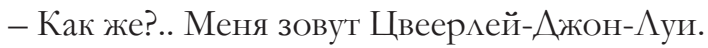

- Чин ваш, сударь? 
- Иностранец.

И Севастьяныч написал на гербовом Аисте крупными словами:

"В Реженский земский суА от иностранного недоросля из Аворян Савелия Жалуева, объяснение”.

- Что ж далее?

- Извольте только написать, я уж вам буду сказывать; пишите: имею я...

- Недвижимое имение, что ми? - спросиц Севастьяныч.

- Нет-с: имею я несчастную слабость...

- К крепким напиткам, что ми? о, это весьма непохваАьно...

- Нет-с: имею я несчастную слабость выходить из моего тела...

- Кой чёрт! - вскричал Севастьяныч, кинув перо, - Аа вы меня морочите, сударь!

- Уверяю вас, что говорю сущую правАу, пишите, только знайте: пятьАесят рублей вам за одну просьбу Аа пятьдесят ещё, когда выхлопочете Аело...

И Севастьяныч снова принялся за перо.

“Сего 20 октября ехац я в кибитке, по своей надобности, по реженскому тракту, на одной подводе, и как на Аворе было холодно, и Аороги Реженского уезда особенно дурны...”

- Нет, уж на этом извините, - возразиц Севастьяныч, - этого написать никак нельзя, это Аичности, а Аичности в просьбах помещать указами запрещено...

- По мне, пожалуй; ну, так просто: на дворе было так холодно, что я боянся заморозить свою Аушу, Аа и вообще мне так захотелось скорее приехать на ночлег... что я не утерпец... и, по своей обыкновенной привычке, выскочиц из моего тела...

- Помилуйте! - вскричал Севастьяныч.

- Ничего, ничего, продолжайте; что ж делать, если такая у меня привычка... ведь в ней ничего нет противозаконного, не правда $\Lambda$ ?

- Та-ак-с, - отвечал Севастьяныч, - что ж далее?

- Извольте писать: выскочил из моего тела, уклал его хорошенько во внутренности кибитки... чтобы оно не выпало, связац у него руки вожжами и отправицся на станцию в той надежде, что цошадь сама прибежит на знакомый Авор...

- Аолжно признаться, - заметил Севастьяныч, - что вы в сём случае поступили очень неосмотрительно. 
- Приехавши на станцию, я взцез на печку отогреть Аушу, и когАа, по расчислению моему, АошаАь Аолжна была возвратиться на постоялый Авор...

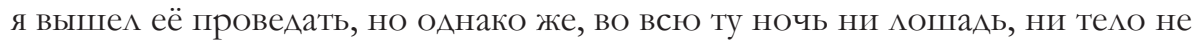
возвращались. На Аругой Аень утром я поспешиц на то место, гАе оставиА кибитку... но уже и там её не было... полагаю, что бездыханное моё тело от

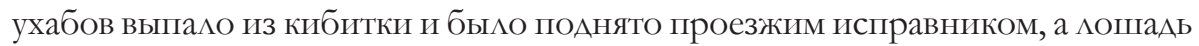
уплелась за обозами... После трёхнелельного тщетного искания я, уведомившись ныне о объявлении Реженского земского суда, коим вызываются вцалельцы найденного тела, покорнейше прошу оное моё тело мне вылать, яко законному своему владельцу... к чему присовокупляю покорнейшую просьбу, Аабы благоволил вышеписанный суд слелать распоряжение, оное тело моё предварительно опустить в холодную воду, чтобы оно отош $о$; если же от случившегося падения есть в том часто упоминаемом теле какой-либо изъян или оное от мороза гАе-либо попортилось, то оное чрез уезАного мекаря приказать поправить на мой кошт и о всём том учинить как законы повелевают, в чём и подписуюсь.

- Ну, извольте же подписывать, - сказац Севастьяныч, окончив бумагу.

- Подписывать! мегко сказать! говорят вам, что у меня теперь со мною рук нету - они остались при теле; подпишите вы за меня, что за неимением рук...

- Нет! извините, - возразиц Севастьяныч, - этакой и формы нет, а просьб, писанных не по форме, указами принимать запрещено; если вам угодно: за неумением грамоты...

- Как заблагорассудите! по мне всё равно.

И Севастьяныч подписал: “К сему объяснению за неумением грамоты, по собственной просьбе просителя, губернский регистратор Иван Севастьянов сын Благосердов руку прицожил”.

- Чувствительнейше вам обязан, почтеннейший Иван Севастьянович! Ну, теперь вы похлопочите, чтоб это дело поскорее решили; не можете себе вообразить, как неловко быть без тела!.. а я сбегаю покуда повидаться с женою, будьте уверены, что я уже вас не обижу.

- Постойте, постойте, ваше благородие! - вскричац Севастьяныч, - в просьбе противоречие. Как же вы без рук уклались или уклали в кибитке своё тело? Тьфу к чёрту, ничего не понимаю.

Но ответа не было. Севастьяныч прочёл ещё раз просьбу, начал наА нею Аумать, думац, думац... 
КогАа он проснулся, ночник погас и утренний свет пробился сквозь обтянутое пузырём окошко. С АосаАою он взглянул на пустой штоф, преА ним стоявший; эта АосаАа выбила у него из головы ночное происшествие; он забрац свои бумаги не посмотря и отправился на барский Авор в надежАе там опохмелиться.

Заседатель, выпив рюмку водки, принялся разбирать Севастьянычевы бумаги и напал на просьбу иностранного недоросля из Аворян.

- Ну, брат Севастьяныч, - вскричал он, прочитав её, - ты вчера на сон грядущий порядком подтянул; экую околёсину нагородиц! Послушайте-ка, Андрей Игнатьевич, - прибавиц он, обращаясь к уезАному мекарю, - вот нам какого просителя Севастьяныч предоставил. - И он прочёл уезАному ^екарю курьёзную просьбу от слова до слова, помирая со смеху.

- Пойлёмте-ка, господа, - сказал он наконец, - вскроемте это болтАивое тело, Аа если оно не отзовётся, так и похороним его подобру-позАорову, в город пора.

Эти слова напомнили Севастьянычу ночное происшествие, и как оно ни странно ему казалось, но он вспомниц о пятидесяти рублях, обещанных ему просителем, если он выхлопочет ему тело, и серьёзно стал требовать от заседателя и мекаря, чтоб тело не вскрывать, потому что этим можно его перепортить, так что оно уже никуда не будет годиться, а просьбу записать во входящий обыкновенным порядком.

Само собою разумеется, что на это требование Севастьянычу отвечали советами протрезвиться, тело вскрыли, ничего в нём не нашли и похоронили.

После сего происшествия мертвецова просьба стала ходить по рукам; везде её списывали, Аополняли, украшали, читали, и Аолго реженские старушки крестились от ужаса, её слушая.

Предание не сохранило окончания сего необыкновенного происшествия: в одном сосеАнем уезде рассказывали, что в то самое время, когАа Аекарь дотронулся до тела своим бистурием, владелец вскочил в тело, тело поднялось, побежало и что за ним Севастьяныч Аолго гнался по Аеревне, крича изо всех сил: “Аови, Аови покойника!”

В Аругом же уезде утвержАают, что владелец и до сих пор кажАое утро и вечер приходит к Севастьянычу, говоря: “Батюшка Иван Севастьяныч, что ж моё тело? когда вы мне его выдадите?” - и что Севастьяныч, не теряя бодрости, отвечает: “А вот собираются справки”. Тому прошло уже мет Авадцать. 


\section{Referências}

GOMIDE, Bruno Barretto (org.). Nova antologia do conto russo (1792-1998). São Paulo: Editora 34, 2011.

ODOEVSKII, V. F. The Salamander and Other Gothic Tales. Evanston: Northwestern University Press, 1992. Tradução e introdução de Neil Cornwell.

ODÓIEVSKI, V. F. Pióstrye skárki. Skárki diéduchki Iriniéia. Moscou: Khudójestvennaia Literatura, 1993. Disponível no site az.lib.ru (consultado em $1^{\circ}$ de setembro de 2017). 